\title{
PENGARUH PENGGUNAAN BINDER ALAMI PADA PROSES FINISHING KULIT CAKAR AYAM TERSAMAK TERHADAP KEKUATAN SOBEK DAN KETAHANAN GOSOK CAT
}

\section{THE EFFECT OF NATURAL BINDER AT THE FINISHING PROCESS OF TANNED CHICKEN SHANK SKIN ON THE TORN STRENGTH AND PAINT ABRASIVE RESISTANCE}

\author{
Sri Sumarni ${ }^{1 *}$, Suharjono Triatmojo ${ }^{2}$, dan Nurliyani ${ }^{2}$ \\ ${ }^{1}$ Akademi Teknologi Kulit, Jl. Ringroad Selatan, Glugo Panggungharjo, Sewon Bantul, Yogyakarta \\ ${ }^{2}$ Fakultas Peternakan, Universitas Gadjah Mada, Jl. Fauna No. 3, Bulaksumur, Yogyakarta, 55281
}

\section{INTISARI}

Penelitian ini bertujuan untuk mempelajari penggunaan binder alami (putih telur dan kasein dari susu sapi segar), sebagai pengganti binder paten pada proses finishing kulit cakar ayam tersamak terhadap kekuatan sobek dan ketahanan gosok cat. Bahan yang digunakan yaitu kulit cakar ayam dengan menggunakan perlakuan variasi konsentrasi binder alami, yaitu: 5, 10, dan 15\% (b/v) dan dosis penggunaan: 5, 10, dan 15\% (v/v) kemudian diuji kekuatan sobek dan ketahanan gosok. Data kekuatan sobek dan ketahanan gosok cat dianalisis menggunakan Rancangan Acak Lengkap pola faktorial (3 x 3). Jika terdapat perbedaan yang nyata, uji dilanjutkan dengan Duncan's New Multiple Range Test (DMRT). Hasil penelitian menunjukkan bahwa tidak terdapat perbedaan yang nyata pada binder alami dengan konsentrasi 5, 10, dan 15\% maupun dosis penggunaan 5, 10, dan 15\% terhadap kekuatan sobek dan ketahanan gosok cat dengan kain basah, tetapi terdapat perbedaan yang nyata terhadap ketahanan gosok cat dengan kain kering. Binder alami kasein menunjukkan pengaruh yang sangat nyata $(\mathrm{P}<0,01)$ baik konsentrasi, dosis penggunaan, maupun interaksinya. Hasil uji t masing-masing bahan binder menunjukkan bahwa terdapat perbedaan yang nyata antara bahan binder albumin, kasein, dan campuran dengan bahan binder paten Leuron E dan Compact terhadap ketahanan gosok cat dengan kain basah maupun kain kering $(\mathrm{P}<0,01)$ tetapi tidak terdapat perbedaan yang nyata terhadap kekuatan sobek kulit samak cakar ayam. Semua hasil pengujian ketahanan gosok cat dengan kain basah maupun kain kering terhadap binder alami memenuhi SNI 06.0996.1989. Disimpulkan bahwa penggunaan binder alami dengan konsentrasi 5, 10, dan $15 \%$ maupun dosis penggunaan 5, 10, dan 15\% tidak mempengaruhi kekuatan sobek dan ketahanan gosok cat dengan kain basah, tetapi berpengaruh terhadap ketahanan gosok cat dengan kain kering.

(Kata kunci: Binder alami, Binder paten, Finishing kulit cakar ayam tersamak)

\section{ABSTRACT}

The study was conducted to investigate the use of natural binders as alternative for patent binder in the finishing process of tanned chicken shank skin on the torn strength and paint abrasive resistance. The material applied were skins of chicken shank, treated by concentration and dose of natural and patent binder of 5, 10 and 15\%, respectively. The parameter measured were torn strength and paint abrasive resistance by dry and wet cloth. The data collected were statistical analyzed using 3x3 Factorial Completely Randomized Design. The results showed that there were not significantly different among concentrations and doses of natural binders on the torn strength and paint abrasive resistance with wet cloth, but there were significantly different among them on the paint abrasive resistance with dry cloth. Casein binder showed the significant $(P<0.01)$ effects whether its concentration, doses, or interaction between them. There were significantly different $(P<0.01)$ among albumin, casein, and albumin-casein binder and Leuron $E$ and Compact patent binder on the paint abrasive resistance by wet and dry cloth, but there were not significantly different among them on the torn strength of tanned chicken shank skin. All of the test result for torn strength and paint abrasive resistance with wet and dry cloth met the SNI 06.0996.1989. It is concluded that concentration and doses of natural binder don't affect the torn strength and paint abrasive resistance with wet cloth but do affect the paint abrasive resistance with dry cloth of tanned chicken shank skin.

(Key words: Natural binders, Patent binder, Tanned chicken shank skin finishing)

\footnotetext{
$\bar{*}$ Korespondensi (corresponding author):

Telp. +6281392046078

E-mail: srisumarni53@gmail.com
} 


\section{Pendahuluan}

Kemajuan industri saat ini berkembang dengan pesat, industri kulit tersamak dan barang kulit berperan aktif di dalamnya, karena mampu menumbuhkan kegiatan ekonomi masyarakat Indonesia dan merupakan komoditas non migas yang dapat diandalkan. Pengecatan tutup pada kulit akan berperan menentukan daya tarik konsumen, apabila kulit dicat tutup dapat memberikan hasil yang baik dan memenuhi selera konsumen. Pengecatan tutup yang baik dapat menaikkan kualitas serta melancarkan pemasaran kulit jadi. Sebaliknya apabila hasil pengecatan kurang baik, maka kualitas serta pemasarannya akan menurun.

Binder atau bahan perekat pada proses penyamakan kulit, sering digunakan pada proses finishing kulit/cat tutup. Tujuan dari cat tutup ini adalah untuk mempertinggi daya tarik dan daya tahan keawetan kulit jadinya, yaitu penampilan rajah (nerf pada kulit) seperi aslinya, misalnya: kulit glace kambing, kulit ular pyton, kulit biawak, kulit cakar ayam, kulit ikan, dan kulit buaya. Hampir semua kulit glace dan reptil menggunakan cat tutup yang memakai binder protein/kasein. Diharapkan dengan binder ini kulit menjadi transparan dan rajah (nerf pada kulit) tampak lebih indah seperti aslinya, kulit yang dihasilkan transparan, dengan syarat; tidak mudah retak apabila melekat pada kulit, tahan terhadap panas (sinar matahari), tahan terhadap gesekan, dapat meningkatkan atau menambah daya tarik kulit jadinya, dan lebih tahan terhadap lingkungan fisik maupun kimiawi (Purnomo, 1991).

Finishing mempunyai peranan yang sangat vital, selain menutup kesalahan proses sebelumnya juga melindungi permukaan kulit dan meningkatkan performance dari karakteristik yang diinginkan sehingga daya tarik meningkat yaitu dengan menggunakan binder alami (albumin dan kasein).

Binder dari putih telur dan binder kasein dapat digunakan sebagai perekat pada pengecatan tutup, tetapi dari kedua binder ini masing-masing mempunyai fungsi dan pengaruh yang berbeda, dilihat dari hasil kulit jadinya. Binder dari putih telur merupakan pembentuk lapisan film yang dapat mengkilapkan kulit pada proses glazing (penggosokan dengan kaca), sedangkan binder kasein berfungsi untuk mengisi rajah yang kosong atau terbuka sehingga mencegah lipatan rajah pada kulit.

Binder paten adalah binder impor. Salah satu contohnya adalah Leuron E (binder protein), yaitu binder yang mengandung 2,5\%, chloro 3 methyl phenol, caprolactan 4\%, 2-2 aminodietanol, bersifat kental, berwarna putih, $\mathrm{pH} \pm 8,5 \%$ dan emulsi. Binder compact adalah binder yang mengandung akrilonitril yang mudah terserap kulit, diethylene glicol dan 2-2 aminodietanol yang mempunyai sifat anionik, mengandung bahan solid $\pm 36 \%$, $\mathrm{pH}$ ratarata 7,5 , bahan finishing kulit dan mengandung metilpirod bebas nitrogen (BASF, 1996).

Komposisi bahan kimia cat tutup terdiri atas: zat warna (pigment, aniline), perekat (binder), pelunak (softener, plastizer), pengkilap warna (brightener), pelarut (solvent), pengencer (diluent), bahan anti gesekan (antifriction), bahan pengisi (filler). Walaupun bahan penyusun cat tutup dari bahan-bahan kimia, namun cat tutup tidak berikatan/bereaksi dengan kulit secara kimia, tetapi hanya secara fisik. Cakar ayam bisa diambil kulitnya dan disamak untuk dijadikan barangbarang kerajinan kulit yang cukup berharga, tulangnya diolah menjadi lem (adhesive) yang bermutu tinggi.

\section{Materi dan Metode}

Penelitian terdiri dari 4 tahap yaitu penyamakan kulit, pembuatan binder alami, penerapan binder pada permukaan kulit, dan pengujian fisis. Penyamakan dilakukan terhadap sebanyak 250 lembar kulit cakar ayam dengan menggunakan khrom-nabati. Skema proses penyamakan kulit cakar ayam dapat dilihat pada Gambar 1.

Binder alami dibuat dengan menggunakan putih telur, kasein dari susu sapi segar, dan campuran (putih telur dan kasein dengan perbandingan $1: 1$ ) dengan konsentrasi $5 \%, 10$, dan $15 \%(\mathrm{~b} / \mathrm{v})$ dan dosis penggunaan 5,10 , dan $15 \%$ $(\mathrm{v} / \mathrm{v})$. Skema proses pembuatan binder dari susu sapi segar dapat dilihat pada Gambar 2, sedangkan skema pembuatan binder dari putih telur dan campuran (albumin dan kasein) dapat dilihat pada Gambar 3 dan 4. Sebagai pembanding, digunakan binder paten Leuron $\mathrm{E}$ dan compact masing-masing dengan konsentrasi $10 \%$ dosis dan penggunaan $10 \%$.

Penerapan binder pada permukaan kulit cakar ayam dilakukan dengan cara kulit cakar ayam (yang telah disamak kombinasi khrom-nabati) dibersihkan rajahnya, dicat, difiksasi, kemudian diglasing. Pembersihan rajah dilakukan dengan menggunakan asam asetat dengan cara diulaskan pada kulit cakar ayam untuk menghilangkan debu dan lemak. Pengecatan tutup untuk lapisan dasar (base coat) yang terdiri atas binder, boraks, air, cat anionic, minyak sulfat, amonia, silikone, emulsi, dan gliserin dilakukan dengan cara diulaskan pada kulit cakar ayam dan diulangi sampai tiga kali. Pengecatan dilanjutkan untuk top coat yang terdiri atas lak solvent dan tiner dengan cara diulaskan pada kulit. Formula base dan top coat dapat dilihat pada Tabel 1. Fiksasi dilakukan menggunakan 10\% larutan 


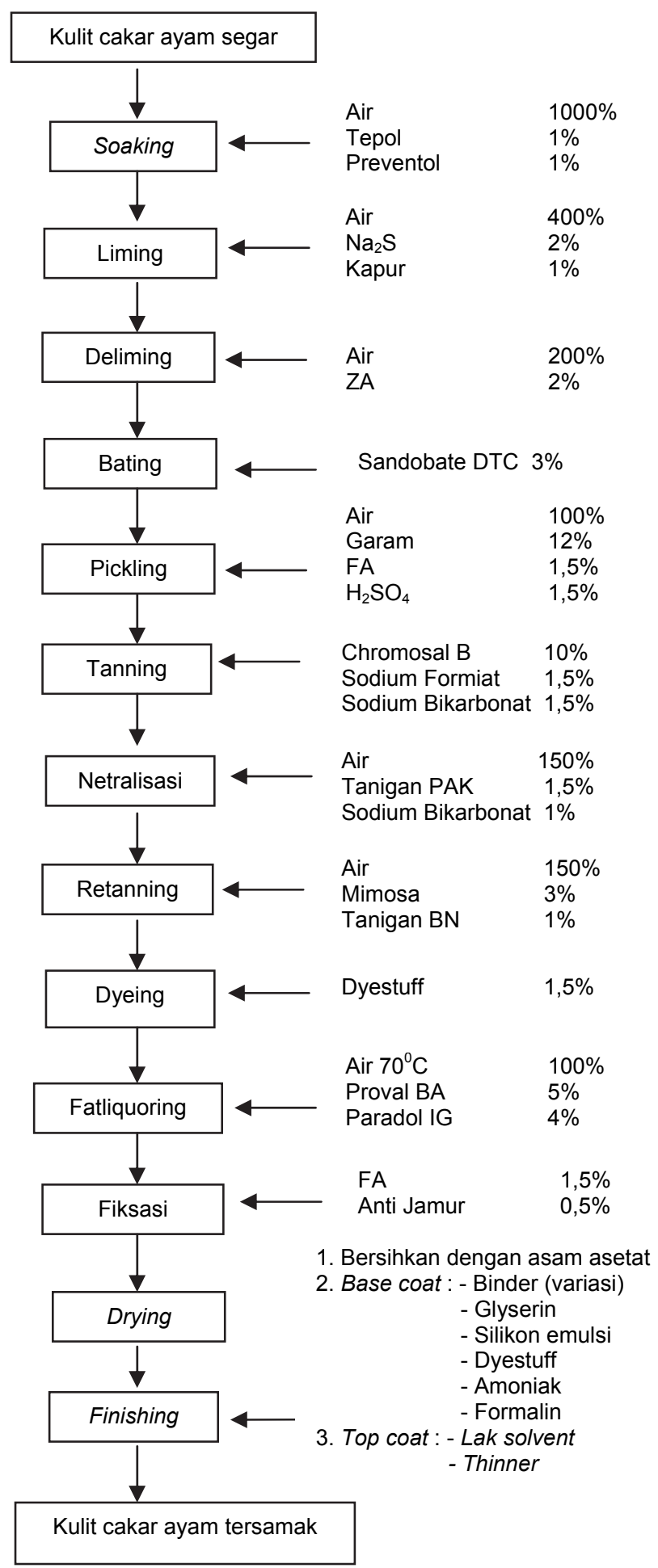

Gambar 1. Skema proses penyamakan kulit cakar ayam (scheme of chicken shank skin tanning procedur).

formalin dengan cara diulaskan pada kulit. Glasing dilakukan dengan cara menggosok kulit dengan botol.

Pengujian fisis yang dilakukan meliputi kekuatan sobek dengan menggunakan mesin Tensile Strength Tester dan ketahanan gosok cat dengan kain basah dan kering dengan menggunakan alat Crock meter yang dilengkapi gray scale.

\section{Analisis data}

Data hasil pengujian kulit cakar ayam yang mendapat perlakuan binder buatan (binder putih telur, kasein, dan campuran keduanya) dianalisis dengan Rancangan Acak Lengkap pola faktorial $3 \times 3$ (3 macam konsentrasi 5, 10, dan 15\%; dan 3 dosis penggunaan 5, 10, dan 15\%). Perbedaan yang signifikan dilanjutkan dengan uji Duncan's new Multiple Range Test (DMRT). 


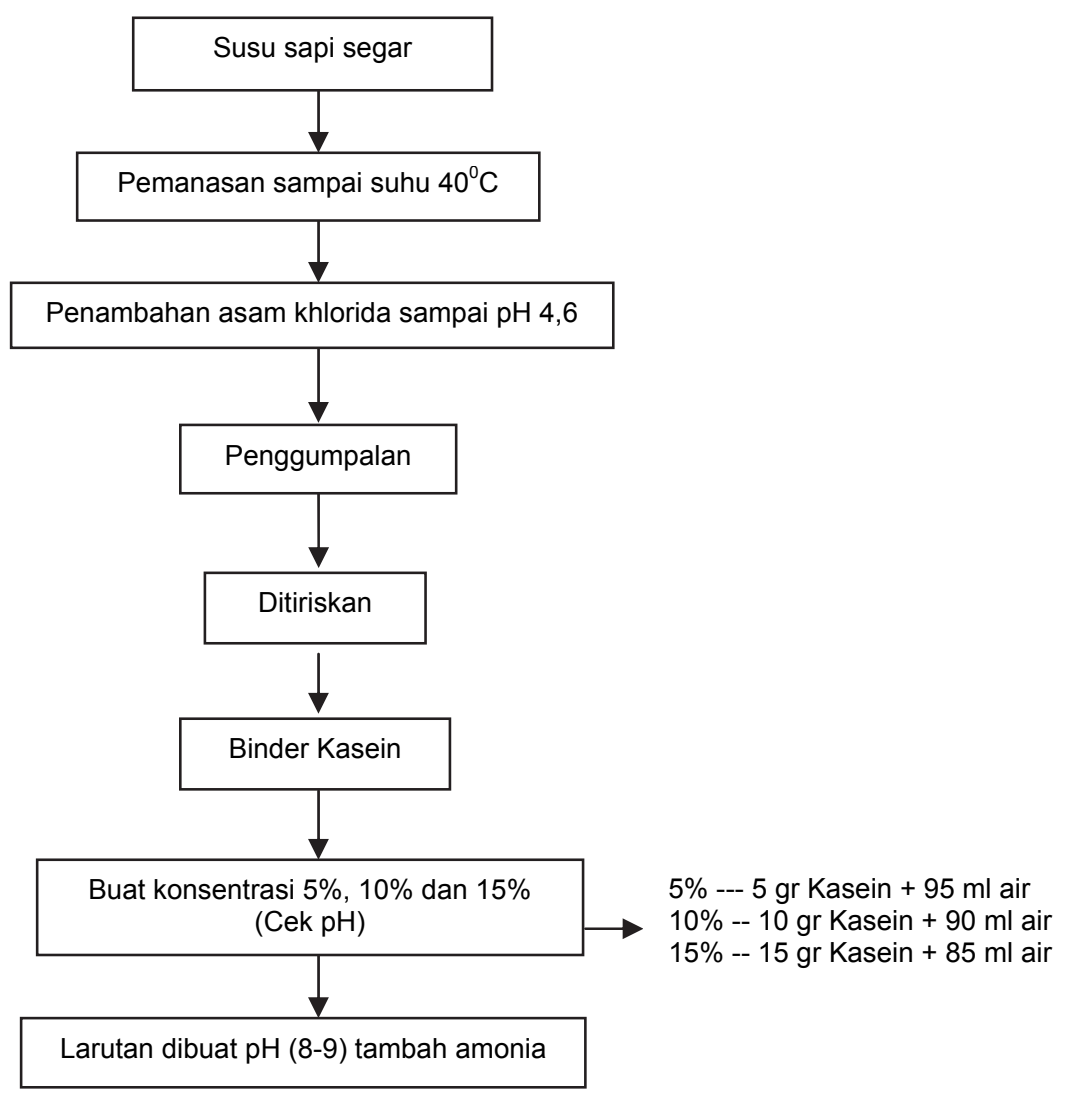

Gambar 2. Skema proses pembuatan binder dari susu sapi segar (production scheme of binder of fresh cow milk).

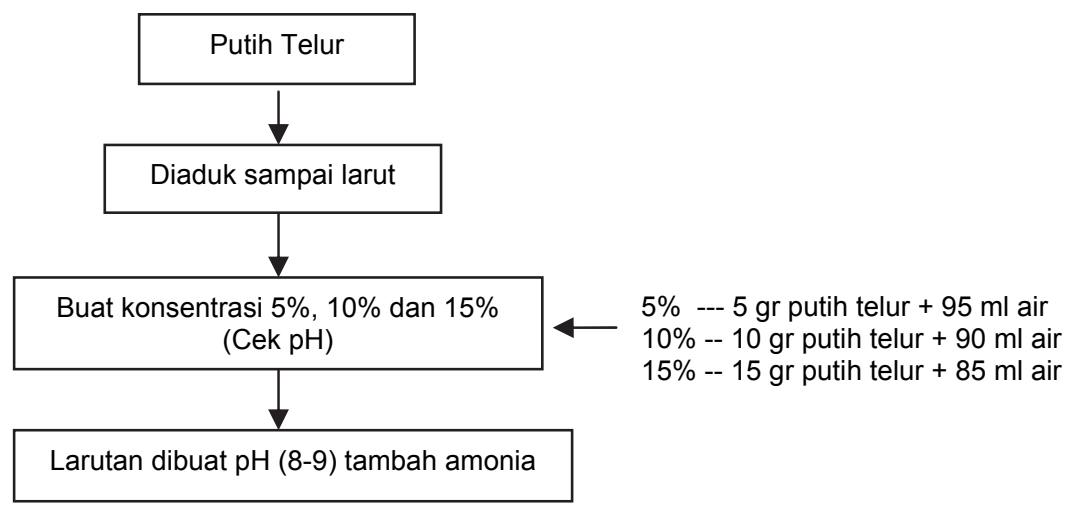

Gambar 3. Skema proses pembuatan binder dari putih telur (production scheme of binder of albumine).

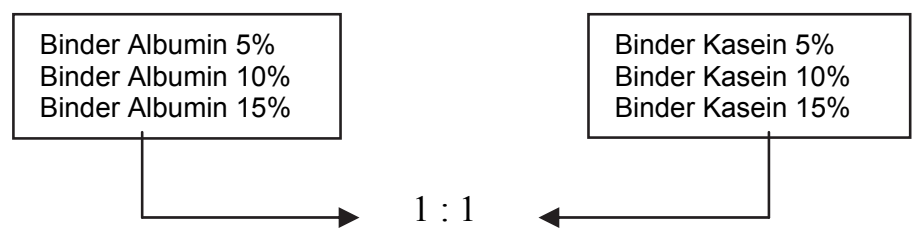

Gambar 4. Skema proses pembuatan binder campuran (albumin dan kasein) (production scheme of binder of albumin and casein mixed).

\section{Hasil dan Pembahasan}

\section{Kimiawi putih telur dan susu sapi}

Hasil pengujian kimiawi pada Tabel 2, menunjukkan bahwa protein pada putih telur dan protein pada susu sapi segar mempunyai perbedaan yang sangat tinggi. Menurut Purnomo (1991), penggunaan binder putih telur secara langsung dapat menyebabkan mengkerutnya kulit, menjadikan permukaan kulit akan lebih kecil dan lama-kelamaan akan menjadi rusak, oleh karena itu untuk membuat binder perlu dilakukan pengenceran. 
Tabel 1. Formula base dan top coat (paten) (patent formula base and top coat)

\begin{tabular}{lcl}
\hline \hline Bahan $($ material $)$ & Bagian (composition) & \multicolumn{1}{c}{ Fungsi (function) } \\
\hline Base coat & 200 & Anti air (waterproff) \\
Resin acrylic & 50 & Anti gores (scratch quard) \\
Resin urethane & Variasi $(5,10,15 \%)($ variation $(5,10,15 \%)$ & Perekat (persentase dari $1000 \mathrm{ml})$ \\
Binder & 50 & Pengisi (filler) \\
Filler & 25 & Penetrasi (penetration) \\
Penetrator & 125 & Pewarna (coloring) \\
Pigment & $1000-(450+$ dosis binder $)$ & Pelarut (solvent) \\
Air $($ water $)$ & 1000 & ml \\
Jumlah $($ total $)$ & & \\
Top coat & 200 & Pengkilap (shiness) \\
Lak solvent & 800 & Anti gores (scratch quard) \\
Supper tinner & 1000 & ml \\
Jumlah $($ total $)$ & &
\end{tabular}

Sumber: BASF (1996).

Tabel 2. Hasil pengujian kimiawi putih telur dan susu sapi segar (chemical analyses of albumine and fresh dairy milk)

\begin{tabular}{lcccc}
\hline \hline \multirow{2}{*}{ Jenis (item) } & \multicolumn{4}{c}{ Parameter } \\
\cline { 2 - 5 } & $\mathrm{pH}$ & $\mathrm{BJ}$ (viscosity) & Kadar air (moisture) & Kadar protein (protein) \\
\hline Putih telur (albumen) & $7,00 \pm 0,10$ & $1,85 \pm 0,01$ & $35,00 \pm 0,13$ & $12,53 \pm 0,22$ \\
Susu sapi segar (dairy milk) & $6,47 \pm 0,11$ & $0,9741 \pm 0,05$ & $87,33 \pm 0,52$ & $2,63 \pm 0,13$ \\
\hline
\end{tabular}

Albumin mempunyai sifat kilap yang baik tetapi keras dan rapuh jika terlalu tebal pada penggunaannya (Sharpouse, 1971), adapun protein pada susu sapi segar (kasein) mengandung lemak sebagai bahan anti gesekan dan membantu meningkatkan daya kilap.

Penggunaan binder protein perlu dilakukan glazing untuk mengkilapkan rajah kulit dengan menggunakan kerang (yang permukaannya halus) atau dengan botol dengan cara menggosokgosokkan searah rajah, agar rajah tidak rusak dan mengkilap.

Komposisi bahan kimia cat tutup untuk setiap jenis kulit dan jenis penyamakan berbeda-beda. Perbedaan komposisi bahan kimia ini juga akan mengakibatkan perbedaan perlakuan, pembuatan formula cat tutup dan sistem atau metode pengecatan itu sendiri. Secara umum cat kulit terdiri atas: zat warna (pigment, aniline), perekat (binder), pelunak (softener, plastizer), pengkilap warna (brightener), pelarut (solvent), pengencer (diluent), bahan anti gesekan (antifriction), bahan pengisi (filler). Bahan penyusun cat tutup dari bahan-bahan kimia, namun cat tutup tidak berikatan atau bereaksi dengan kulit secara kimia, tetapi hanya secara fisik (Purnomo, 1992).

Pelapisan dasar (base coat) bertujuan untuk meningkatkan keseragaman kepadatan kulit karena bahan yang dipakai adalah binder dan filler yang dapat mengisi serat kulit yang kosong. Penggunaan pelunak agar lapisan tidak mudah pecah. Pelapisan atas (top coat) bertujuan untuk meningkatkan ketahanan gosok serta memberikan efek kilap pada kulit jadinya.

\section{Kekuatan sobek}

Belum adanya SNI tentang pengujian fisis dari penyamakan kulit cakar ayam sebagai perbandingan (standar), maka hasil pengujian fisis binder alami dibandingkan dengan hasil pengujian fisis binder paten (impor) yaitu Leuron $\mathrm{E}$ dan compact dengan konsentrasi $10 \%$, dosis $10 \%$ (BASF, 1996). Kekuatan sobek kulit cakar ayam tersamak dengan binder paten dan alami masingmasing dapat dilihat pada Tabel 3 dan 4 .

Tabel 3. Kekuatan sobek kulit cakar ayam tersamak dengan binder paten $(\mathrm{kg} / \mathrm{cm})($ torn strength of tanned chicken shank skin with patent binder $(\mathrm{kg} / \mathrm{cm}))$

\begin{tabular}{ccc}
\hline \hline Ulangan (replication) & Leuron E 10\% & Compact $10 \%$ \\
\hline 1 & 19,24 & 22,00 \\
2 & 16,92 & 14,83 \\
3 & 17,72 & 20,55 \\
\hline
\end{tabular}


Berdasarkan hasil analisis CRD pola faktorial (3x3) menunjukkan bahwa pengaruh konsentrasi maupun dosis binder albumin, kasein maupun campurannya tidak menunjukkan pengaruh yang nyata terhadap kekuatan sobek kulit cakar ayam tersamak. Demikian pula interaksi antara konsentrasi dan dosis tidak signifikan, kecuali pada binder albumin $(\mathrm{P}<0,10)$.

Pengaruh terbaik terhadap kekuatan sobek dijumpai pada konsentrasi binder campuran meskipun tidak signifikan. Demikian pula dosis yang berpengaruh adalah dosis binder campuran terhadap kekuatan sobek. Penggunaan binder alami berdasarkan konsentrasi ataupun dosis, secara umum berdampak tidak nyata terhadap kekuatan sobek kulit cakar ayam tersamak.

Berdasarkan hasil uji t antara masing-masing binder menunjukkan berbeda tidak nyata terhadap kekuatan sobek kulit tersamak. Sehingga antara masing-masing perlakuan binder buatan dianggap sama satu sama lain. Namun kekuatan sobek tertinggi diperoleh pada perlakuan binder dengan konsentrasi $15 \%$ dan dosis $10 \%$; dan terendah pada binder albumin konsentrasi 10\% dan 5\%. Kekuatan sobek yang dihasilkan dengan perlakuan binder alami dan binder paten belum menunjukkan perbedaan yang signifikan.

\section{Ketahanan gosok cat}

Hasil uji ketahanan gosok cat pada kulit cakar ayam dengan kain basah dan kering dengan nilai skala abu-abu (grey scale) menunjukkan berbeda tidak nyata, baik dengan penggunaan binder impor Leuron $\mathrm{E}$ ataupun binder compact (Tabel 5).

Ketahanan gosok cat dengan kain basah. Hasil analisis uji ketahanan gosok cat dengan kain basah tersaji pada Tabel 6. Pengaruh konsentrasi dan dosis masing-masing binder alami menunjukkan berbeda tidak nyata terhadap ketahanan gosok cat dengan kain basah, kecuali pada penggunaan konsentrasi 5\% binder albumin terlihat berbeda nyata dengan konsentrasi binder albumin 10 dan $15 \%$.

Pengaruh dosis secara umum masing-masing binder alami masih berimbang satu sama lain; dengan demikian dalam penggunaan binder alami hanya faktor konsentrasi yang berpengaruh terhadap ketahanan gosok cat kain basah.

Hasil uji t antara macam binder alami dan paten terhadap ketahanan gosok kain basah menunjukkan perbedaan yang tidak nyata antara binder alami dan binder paten Leuron E. Sebaliknya binder alami dengan binder paten compact terlihat adanya perbedaan yang sangat nyata $(\mathrm{P}<0,01)$ terhadap ketahanan gosok cat kain basah.
Ketahanan gosok cat kain basah terendah dijumpai pada binder compact. Ketahanan tertinggi dijumpai pada binder albumin dengan konsentrasi dan dosis $5 \%$.

Ketahanan gosok cat dengan kain kering. Hasil analisis uji ketahanan gosok cat dengan kain kering tersaji pada Tabel 7. Hasil uji analisis CRD pola faktorial pengaruh konsentrasi dan dosis binder alami menunjukkan adanya pengaruh yang sangat nyata $(\mathrm{P}<0,01)$ dari konsentrasi, dosis serta interaksinya terhadap ketahanan gosok cat pada binder kasein. Sedangkan, pada binder albumin dan campuran, hanya faktor konsentrasi yang berdampak baik terhadap ketahanan gosok cat dengan kain kering.

Hasil uji $\mathrm{t}$ menunjukkan bahwa antara masing-masing binder alami tidak menunjukkan perbedaan yang nyata terhadap ketahanan gosok cat kain kering, kecuali antara binder kasein dengan binder Leuron $\mathrm{E}$ atau binder compact $(\mathrm{P}<0,01)$. Ketahanan gosok cat kain kering terendah dijumpai pada binder kasein, sedang tertinggi pada binder Leuron E dan binder compact.

Hasil uji DMRT terhadap konsentrasi dan dosis menunjukkan bahwa rerata konsentrasi binder albumin adalah 2,33, 2,33 dan 1,66 masingmasing untuk konsentrasi $\mathrm{K}_{5}, \mathrm{~K}_{10}$, dan $\mathrm{K}_{15}$, sedangkan untuk dosis $\mathrm{D}_{5}, \mathrm{D}_{10}$, dan $\mathrm{D}_{15}$ masingmasing 2,33, 2,00, dan 2,00.

Menurut Wirahadikusumah (1981), sifat asam basa suatu protein dalam larutan sebagian besar ditentukan oleh gugus $\mathrm{R}$ asam aminonya yang dapat terionisasi. Gugus $\mathrm{NH}_{2}$ dan $\mathrm{COOH}$ yang terdapat pada kedua ujung rantai polipeptida sedikit sekali menunjang sifat asam-basa protein tersebut. Pada asam amino bebas, protein juga mempunyai titik isoelektrik, yaitu pada $\mathrm{pH}$ yang menunjukkan jumlah muatan positif dan negatif sama dalam protein itu, sehingga pada keadaan ini daya larut protein adalah minimum. Suatu larutan apabila $\mathrm{pH}$ di atas $\mathrm{pH}$ isoelektrik, protein bermuatan negatif dan akan bergerak ke anoda, sehingga pada pembuatan binder alami yaitu binder albumin, kasein, dan campuran (albumin dan kasein) dibuat $\mathrm{pH}$ 8-9 maka binder alami tersebut bermuatan negatif. Penerapan pada proses finishing kulit cakar ayam yang bermuatan positif (kulit cakar ayam disamak khrom-nabati), maka akan terjadi gaya tarikmenarik antara molekul-molekul pada binder dan permukaan kulit, sehingga terjadi ikatan yang sangat kuat (Purnomo, 1991). Hal ini terlihat pada proses finishing, cat akan terikat kuat pada permukaan kulit sehingga, waktu diuji ketahanan gosoknya dengan kain basah dan kering tidak luntur. 





Tabel 7. Ketahanan gosok cat dengan kain kering dari kulit cakar ayam tersamak dengan binder alami pada konsentrasi dan dosis yang berbeda (paint abrassive resistance by dry cloth of tanned chicken shank skin with natural binder at different concentration and doses)

\begin{tabular}{|c|c|c|c|c|c|c|c|c|c|}
\hline \multirow{2}{*}{ Bahan (material) } & \multicolumn{9}{|c|}{ Kombinasi konsentrasi - dosis (\%) (concentration-doses combination (\%)) } \\
\hline & $(5-5)$ & $(5-10)$ & $(5-15)$ & $(10-5)$ & $(10-10)$ & $(10-15)$ & $(15-5)$ & $(15-10)$ & $(15-15)$ \\
\hline Albumin (albumine) & $3,5 \pm 0$ & $4,0 \pm 0$ & $4,0 \pm 0$ & $3,5 \pm 0$ & $3,5 \pm 0$ & $3,5 \pm 0$ & $3,5 \pm 0$ & $3,5 \pm 0$ & $3,5 \pm 0$ \\
\hline Kasein (casein) & $3,5 \pm 0$ & $3,5 \pm 0$ & $4,0 \pm 0$ & $3,5 \pm 0$ & $4,0 \pm 0$ & $3,5 \pm 0$ & $3,5 \pm 0$ & $3,5 \pm 0$ & $3,5 \pm 0$ \\
\hline \multirow{3}{*}{$\begin{array}{l}\text { Albumin + kasein } \\
\text { (albumin + casein })\end{array}$} & $3,5 \pm 0$ & $3,5 \pm 0$ & $3,5 \pm 0$ & $3,5 \pm 0$ & $3,5 \pm 0$ & $3,5 \pm 0$ & $4,0 \pm 0$ & $4,0 \pm 0$ & $4,0 \pm 0$ \\
\hline & \multicolumn{5}{|c|}{ Rerata konsentrasi (concentration average) } & \multicolumn{4}{|c|}{ Rerata dosis (doses average) } \\
\hline & $5 \%$ & 10 & & $15 \%$ & & $5 \%$ & & & $15 \%$ \\
\hline Albumin (albumine) & $3,83 \pm 0^{\mathrm{a}}$ & 3,50 & & $3,50 \pm 0^{\mathrm{b}}$ & & $3,50 \pm 0^{\mathrm{b}}$ & 3,67 & & $3,67 \pm 0^{\mathrm{a}}$ \\
\hline Kasein (casein) & $3,67 \pm 0^{\mathrm{a}}$ & 3,67 & & $3,33 \pm 0^{\mathrm{b}}$ & & $3,50 \pm 0^{\mathrm{b}}$ & 3,50 & & $3,67 \pm 0^{\mathrm{a}}$ \\
\hline $\begin{array}{l}\text { Albumin + kasein } \\
(\text { albumin }+ \text { casein })\end{array}$ & $3,50 \pm 0^{\mathrm{b}}$ & 3,50 & & $4,00 \pm 0^{\mathrm{a}}$ & & $3,67 \pm 0^{\mathrm{a}}$ & 3,67 & & $3,67 \pm 0^{\mathrm{a}}$ \\
\hline
\end{tabular}

\section{Kesimpulan}

Binder alami yang dibuat dari albumin, kasein dan campuran (albumin + kasein), dengan konsentrasi 5,10 , dan $15 \%$; serta dosis penggunaan 5, 10, dan $15 \%$ untuk bahan binder pada proses finishing penyamakan kulit cakar ayam masingmasing tidak menunjukkan perbedaan nyata terhadap kekuatan sobek kulit cakar ayam. Binder alami dapat menggantikan binder paten bila dilihat dari hasil uji kekuatan sobek. Kekuatan sobek hasil penggunaan binder alami tertinggi diperoleh dengan konsentrasi $10 \%$ dan dosis penggunaan $10 \%$ yaitu dari bahan campuran albumin + kasein. Pengaruh konsentrasi dan dosis penggunaan binder alami kasein terlihat nyata terhadap ketahanan gosok cat dengan kain kering. Hasil pengujian ketahanan gosok cat dengan kain basah maupun kering yang menggunakan binder alami adalah antara 3-5, jadi menurut SNI 06.0996-1989 memenuhi syarat.

\section{Daftar Pustaka}

BASF. 1996. Pocked Book for Leather Technologiest. Edisi III, 6750, Ludswighafen, Thorstensen, German.

Purnomo, E. 1991. Penyamakan Kulit Reptil. Cetakan I, Kanisius, Yogyakarta.

Purnomo, E. 1992. Penyamakan Kulit Kaki Ayam. Cetakan I, Kanisius, Yogyakarta.

Sharpouse, J. H. 1971. Leather Technician's Hand Book. Leather Producers Association. London.

Wirahadikusumah, M. 1981. Biokimia Protein, Ensim dan Asam Nukleat. Cetakan ketiga ITB Bandung. 